\title{
Single-Channel Flow Injection Spectrophotometric Determination of Nickel Using Furildioxime in Micellar Solution
}

\author{
Najma Memon, ${ }^{1}$ Saima Memon, ${ }^{2}$ Amber R. Solangi, ${ }^{1}$ Rubina Soomro, ${ }^{1}$ and Rabel Soomro ${ }^{1}$ \\ ${ }^{1}$ NCE in Analytical Chemistry, University of Sindh, Jamshoro 76080, Pakistan \\ ${ }^{2}$ Institute of Advanced Studies in Chemical Sciences, University of Sindh, Jamshoro 78060, Pakistan
}

Correspondence should be addressed to Najma Memon, najmamemon@gmail.com

Received 31 October 2011; Accepted 30 November 2011

Academic Editors: A. Sabarudin and S. Sultan

Copyright (C 2012 Najma Memon et al. This is an open access article distributed under the Creative Commons Attribution License, which permits unrestricted use, distribution, and reproduction in any medium, provided the original work is properly cited.

\begin{abstract}
A very simple, selective, and fast flow injection spectrophotometeric method is developed for determination of nickel using furildioxime as complexing agent. Micellar solution of brij-35 is employed to solubilize the sparingly soluble complex of Nifurildioxime in buffered aqueous system ( $\mathrm{pH}-9.00$ ). Under optimized conditions, absorbance is linear from 0.02 to $10 \mu \mathrm{g} \mathrm{mL}$ using $500 \mu \mathrm{L}$ sample volume and from 10 to $30 \mu \mathrm{g} \mathrm{mL} \mathrm{L}^{-1}$ using $50 \mu \mathrm{L}$ sample volume of nickel at $480 \mathrm{~nm}$, with $R^{2}=0.9971$ and 0.9916 , respectively. The molar absorption coefficient and Sandell's sensitivity were $6.0 \times 10^{3} \mathrm{~L} \mathrm{~mol}^{-1} \mathrm{~cm}^{-1}$ and $0.01 \mathrm{ng} \mathrm{cm}{ }^{-2}$, respectively. The sample throughput of the method is 120 samples per hour with RSD of $0.01-0.2 \%$ for 0.02 to $10 \mu \mathrm{g} \mathrm{mL}{ }^{-1}$ nickel $(n=5)$, indicating that the method is highly precise and reproducible. Interference from cobalt is removed by Nitroso R-saltmodified XAD-16. The developed method is validated by analysing certified reference materials and is applied to assess nickel content of commercially available cigarettes.
\end{abstract}

\section{Introduction}

Interest in the determination of nickel has increased over the last few years because of the influence of this metal on humans. Adverse effects of inorganic, water-soluble nickel species occur after contact with skin, causing nickel dermatitis. After inhalation, respiratory tract irritation and asthma can also result. Besides carcinogenensis, bioassays in animals showed that certain nickel compounds are potent carcinogens when administered via parenteral routes [1].

In rapidly expanding analytical fields, such as environmental, biological, and material monitoring of trace metals, there is an increasing need to develop simple, sensitive, selective, and reproducible analytical techniques that do not use expensive or complicated test equipments. Many sensitive instruments, such as spectrofluorimetry, X-ray fluorescence spectrometry, neutron activation analysis, atomic absorption spectrophotometery, and chemiluminescence have been widely applied for the determination of nickel [2-8]. However, spectrophotometric methods still have the advantages of simplicity and require no expensive or complicated test equipment. Also, there are various automated spectrophotometric methods (flow injection based) for the determination of nickel, but due to extraction of complex in organic solvents, complicated FIA setups are used [9]. A flow Injection visible diffused reflectance method by precipitating nickel with furildioxime was reported but reproducibility of peak heights is not satisfactory [10].

Spectrophotometrically, nickel is determined by using complexing agents, such as bis(acetylacetone)ethylenediimine, 2-(2-Quinolylazo)-5-diethylaminoaniline, dimethylglyoxime, and furildioxime $[9,11-13]$.

Oximes are group of compounds, which reacts with limited number of metal ions, hence come under the umbrella of selective reagents. These form water-insoluble complexes extractable into organic solvents, but the extraction is not $100 \%$ due to partial solubility of complexes. Furildioxime forms complex with nickel that is absorbed in chloroform at $438 \mathrm{~nm}$ [12]. Inspite of high selectivity of this reagent toward nickel, its use is limited due to sparingly soluble precipitates and solubilizing of Ni-furildioxime [14]. Recently, dissolution of precipitate formed by $\mathrm{Ni}$-furildioxime is tried by ultrasonic irradiation but quick transfer from ultasnoic 
bath to spectrophotometer is the condition for analysis as turbidity reappears [15].

The ability of surfactants to solubilize the water-insoluble complexes in homogenous environment can overcome this problem. There is only one report that addresses the flow injection determination of nickel using pyridylazoresorcinol in TX-100 solution but it is laboratory exercise published by undergraduate students and proper optimization is not worked out [16]. Micellar solutions in FI have unique feature of sensitivity and speed of analysis with less waste for treatment. Micellar solutions obviate the need of phase separator in FIA systems which resulted in simple setups with more reproducible assays $[14,17,18]$.

This study is aimed at developing simple, rapid, selective, and sensitive assay for nickel. Furildioxime is selected as complexing reagent due to its selective behavior toward nickel. Micellar solutions are used as microheterogonous system to carry out complexation reaction, and flow injection is employed to automate the system and to provide highthroughput determination. Assay is made selective by removing cobalt, major interfering metal ion, by using NitrosoRsalt modified XAD-16.

\section{Experimental}

2.1. Apparatus. A four-channel peristaltic pump (Gilson Minipuls 3) was used to propel the carrier stream, equipped with PVC pump tubes with i.d $0.5 \mathrm{~mm}$ (anachem). Samples were injected via rotary PTFE valve (Rheodyne 5020). PTFE $0.5 \mathrm{mmi}$.d. tubing was used throughout the remainder system. The detector used was Spectronic 20 at $488 \mathrm{~nm}$ equipped with $100-\mu \mathrm{L}$ flow through cell. Yew strip chart recorder was used to record the signal. Shimadzu UV365 spectrophotometer was used to record the spectra of nickel-furildioxime system. A Perkin-Elmer (Lamda-2, Germany) double-beam spectrophotometer was used for the comparison of the results. A digital $\mathrm{pH}$ meter (WTW, Inolab $\mathrm{pH}$ level 1, Germany) was used to measure the $\mathrm{pH}$ of the solution.

2.2. Reagents. All chemicals used were of analytical reagent grade or highest purity available. Double-distilled deionized water was used throughout.

2.3. Furildioxime Solution. A 5\% solution was prepared by dissolving the $5.0 \mathrm{~g}$ of furildioxime (Merck, Darmstadt, Germany) in $100 \mathrm{~mL}$ of methanol (Merck).

2.4. Nickel(II) Standard Solution. A $100 \mathrm{~mL}$ stock solution ( $1 \mathrm{mg} \mathrm{mL}^{-1}$ ) of nickel was prepared by dissolving appropriate amount of nickel sulfate (Fluka, Switzerland) in doubledistilled deionized water containing $1 \mathrm{~mL}$ of $1+1$ nitric acid. More diluted solutions were prepared from this stock solution freshly when required in double-distilled deionized water.

2.5. Brij-35 Stock Solution (5\%). A $500 \mathrm{~mL}$ stock solution of Brij-35 (Merck) was prepared by dissolving $50 \mathrm{~g}$ of Brij-35 in

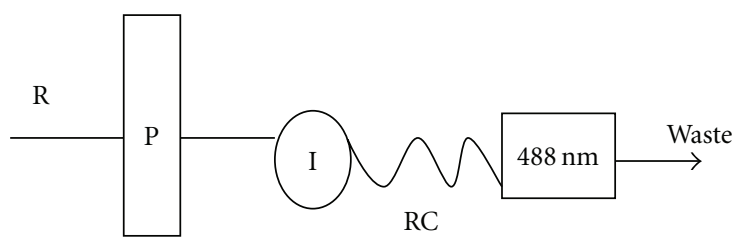

FIGURE 1: Block diagram for the FIA setup used for determination of nickel using furildioxime.

250-300 mL of water and sonicated for 15 minutes and was diluted to mark with double-distilled deionized water when become transparent.

2.6. Other Solutions. Solutions of the large number of anions, cations, and complexing agents were prepared from their analaR grade or equivalent grade water-soluble salts. All glassware was kept in nitric acid $(1+1)$ for at least a day and then washed with deionized water. Stock solutions and environmental water sample were kept in polypropylene bottles containing $1 \mathrm{~mL}$ concentrated nitric acid.

\subsection{Procedure}

2.7.1. Preparation of Reagent for FIA. A single-channel FIA manifold was used throughout. Reagent " $\mathrm{R}$ " was prepared by taking $0.05 \mathrm{~mL}$ of Brij-35 (5\%) and $5.0 \mathrm{~mL}$ of buffer $\left(\mathrm{NH}_{4} \mathrm{Cl} / \mathrm{NaOH}\right.$ buffer, $\mathrm{pH}=9.00$, and $\left.I=1\right)$ was mixed and $0.4 \mathrm{~mL} \mathrm{5 \%}$ furildioxime was added and mixed well, then diluted to $25.0 \mathrm{~mL}$ with deionized water. The reagent was pumped at the flow rate of $2.0 \mathrm{~mL} \mathrm{~min}^{-1}$. The sample was injected at position " $I$ " into flowing reagent stream. The sample reacts at point reaction coil "RC" of $100 \mathrm{~cm}$ and is detected at $488 \mathrm{~nm}$ (Figure 1).

2.7.2. Nitroso-R Salt-Modified XAD-16. Amberlite XAD$16(5 \mathrm{~g})$ and $50 \mathrm{~mL}$ of aqueous $0.1 \%$ nitroso-R salt were stirred with the help of magnetic stirrer. Absorbance of nitroso-R salt in solution was monitored continuously using UV-Visible spectrophotometer. When the absorbance of nitroso-R salt became constant, the resin was filtered and dried. The amount of chelating reagent required for the modification of surface of XAD-16 was optimized by varying the concentration and volumes of nitroso-R salt. Recovery (\%) of nickel was found to be quantitative using $50 \mathrm{~mL}$ of $0.1 \%$ nitroso-R salt.

\section{Results and Discussion}

Various chemical and FIA parameters were studied to get optimum signal (absorbance). Studied range, and selected parameters are shown in Table 1.

\subsection{Factors Affecting Absorbance of Nickel-Furildioxime Complex}

3.1.1. Absorption Spectra. The absorption spectra of nickelfurildioxime in Brij-35 at $\mathrm{pH} 9.00$ was recorded using 
TABle 1: Selected chemical and FIA parameters obtained with optimization experiments.

\begin{tabular}{lcc}
\hline Parameter & Studied range & Selected value \\
\hline Size of sample loop $(\mu \mathrm{L})$ & $50-500$ & 500 \\
Reagent flow rate $\left(\mathrm{mL} \mathrm{min}^{-1}\right)$ & $1.0-4.2$ & 1.2 \\
Length of reaction coil $(\mathrm{cm})$ & $50-300$ & 100 \\
$\mathrm{pH}$ & $3.5-12.0$ & 9.0 \\
Concentration of reagent $(\%)$ & $0.04-0.25$ & 0.08 \\
$\mathrm{Brij}-35(\%)$ & $0.01-2.0$ & 0.01 \\
$\mathrm{NH}_{4} \mathrm{Cl} / \mathrm{NaOH}(\mathrm{M})$ & $0.04-0.4$ & 0.2 \\
\hline
\end{tabular}

Shimadzu UV-365 spectrophotometer, Japan. The absorption spectrum of nickel-furildioxime shows the maximum absorbance at $480 \mathrm{~nm}$. In all instances, measurements were made at $480 \mathrm{~nm}$ against reagent blank.

3.1.2. Effect of Surfactant Type and Concentration. Various types of surfactants; anionic (sodium dodecyl sulfate), cationic (cetyl trimethyl ammonium bromide), and nonionic (Brij-35) were studied; Brij-35 was found to be the best surfactant for the system. Ionic surfactants were rejected for not providing adequate solubility and high background signal which hampers the determination of metal ions at low concentration. In $0.01 \%$ Brij-35 medium, however, maximum absorbance was observed; hence $0.01 \%$ Brij-35 was used in the determination procedure. It was observed that very little concentration is enough to solublize the complex, while on increasing concentration, the absorbance decreases and remains constant after $0.2 \%$ Brij-35. This may be due to micellar dilution effect and also the viscosity of the system increases with surfactant concentration which in turn decreases absorbance [19].

3.1.3. Effect of $p H$. Effect of $\mathrm{pH}$ was observed by varying $\mathrm{pH}$ of reagent from 3.5-12.0 using $\mathrm{HCl} / \mathrm{NaOH}$ at room temperature. The absorbance was maximum at $\mathrm{pH}$ 9.0, using final concentration of buffer $0.2 \mathrm{M}$ at room temperature $25 \pm 5^{\circ} \mathrm{C}$. Outside this range, the absorbance decreased (Figure 2). This is due to deprotonation of furildioxime at higher $\mathrm{pH}$ which favors the formation of complex with positively charged $\mathrm{Ni}^{2+}$. The same trend is reported for extraction systems and complexation in aqueous medium, this shows that $\mathrm{pH}$-dependant chemistries are not altered in micellar medium [20]. For all subsequent measurements, $0.2 \mathrm{M}$ buffer $\left(\mathrm{NH}_{4} \mathrm{Cl} / \mathrm{NaOH}\right)$ at $\mathrm{pH} 9.0$ was used.

3.1.4. Effect of Reagent Concentration. Different volumes of stock $5 \%$ methanolic solution of furildioxime were added to prepare reagent " $\mathrm{R}$ " for FIA, and fixed concentration of metal ion was injected $(50 \mu \mathrm{L})$. It was observed that on increasing concentration, signal increases up to $0.1 \%$ and then starts decreasing. Low reagent concentration may lead to incomplete complexation, but at higher concentration, the background signal increases and reduces net signal so, reagent concentration of $0.1 \%$ was used for further studies.

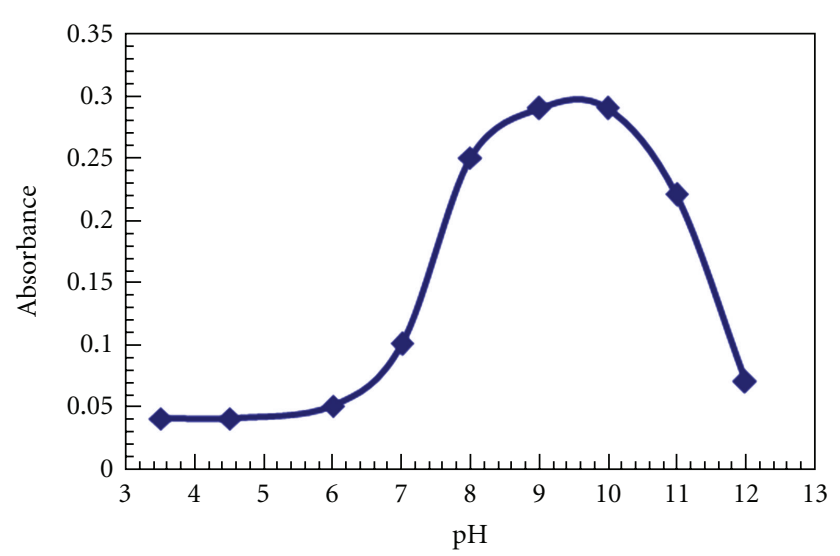

Figure 2: Effect of $\mathrm{pH}$ on the absorbance of nickel-fruildiome complex.

TABLE 2: Salient features of the proposed method.

\begin{tabular}{lc}
\hline Parameter & Optimized value \\
\hline $\mathrm{pH}$ & 9.0 \\
Linear range $\left(\mu \mathrm{g} \mathrm{mL}^{-1}\right)$ & $0.02-30$ \\
Detection Limit $\left(\mathrm{ng} \mathrm{mL}^{-1}\right)$ & 10 \\
Dispersion Coefficient & 4.0 \\
Reproducibility & $0.0-0.2$ \\
Sample throughput & 120 samples per hour \\
\hline
\end{tabular}

3.1.5. Effect of FIA Parameters. Flow parameters like pump speed (flow rate), reaction coil length, and sample volume were studied by varying pump speed, home-made reaction coils from Teflon tubes, and loops of different injection volumes, respectively. There is very small effect on the signal on increasing pump speed. Decrease in absorbance on increasing reaction coil length was observed, this shows that the reaction in micellar medium is spontaneous and delaying the reactants in coil will not shift the equilibrium to produce more products. So, reaction coil length of $100 \mathrm{~cm}$ and pump speed $12 \mathrm{rpm}$ (corresponds to $2.1 \mathrm{~mL} \mathrm{~min}^{-1}$ ) was selected. Although, increasing sample volume increased absorbance from $0.2-0.5$ for $50-500 \mu$ Ls. Large sample volume was used to construct calibration graphs at lower concentrations while $50-\mu \mathrm{L}$ loop was used at higher concentrations which produce sharp peaks.

3.1.6. Analytical Figures of Merit. The absorbance was linear from 0.02 to $10 \mu \mathrm{g} \mathrm{mL}^{-1}$ using $500 \mu \mathrm{L}$ sample volume $(y=0.0927+0.0331)$ and $10-30 \mu \mathrm{g} \mathrm{mL}^{-1}$ using $50-\mu \mathrm{L}$ sample volume $(y=0.0428+0.0764)$ of nickel at $480 \mathrm{~nm}$, with $R^{2}=0.9971$ and 0.9916 , respectively. The molar absorption coefficient and Sandell's sensitivity were $6.0 \times$ $10^{3} \mathrm{~L} \mathrm{~mol}^{-1} \mathrm{~cm}^{-1}$ and $0.01 \mathrm{ng} \mathrm{cm}^{-2}$, respectively.

The sample throughput of the method is 120 samples per hour. The RSD $(n=5)$ is $0.01-0.2 \%$ for 0.02 to $10 \mu \mathrm{g} \mathrm{mL}^{-1}$ nickel, indicating that the method is highly precise and reproducible. Salient features of proposed method are summarized in Table 2. 
TABle 3: Determination of nickel in synthetic mixtures.

\begin{tabular}{llccc}
\hline \multirow{2}{*}{ Sample } & \multirow{2}{*}{ Composition of mixture } & \multicolumn{3}{c}{ Nickel in $\mu \mathrm{g} \mathrm{m}^{-1}$} \\
& & Added & Found & $\%$ Recovery \\
\hline $\mathrm{A}$ & Nickel & 2.0 & 2.0 & 100 \\
$\mathrm{~B}$ & $\mathrm{~A}+\mathrm{V}^{\mathrm{V}}(25$ fold $)$ & 2.0 & 1.8 & 90 \\
$\mathrm{C}$ & $\mathrm{B}+\mathrm{Zn}^{2+}(25$ fold $)+$ & 2.0 & 1.8 & 90 \\
& $\mathrm{Ca}(25$ fold $)$ & & & \\
$\mathrm{D}$ & $\mathrm{C}+\mathrm{Fe}(25$ fold $)+$ & 2.0 & 2.2 & 110 \\
\hline
\end{tabular}

3.1.7. Effect of Foreign Ions. The effect of over 40 cations, anions, and complexing agents were studied on the determination of only $1 \mu \mathrm{g} \mathrm{mL} L^{-1}$ of nickel. The criterion for interference was an absorbance value varying for more than $5 \%$ for the expected value of nickel alone [21]. No interference was found from the following; 1000-fold amount of sulfate, sulfite, nitrate, bromide, chloride, iodide, $\mathrm{Na}, \mathrm{K}$, $\mathrm{Ca}, \mathrm{NH}_{4}{ }^{+}$, tartarate, citrate, thiosulfate, hydrogen phosphate, and azide. 50-fold amount of $\mathrm{Fe}^{2+}, \mathrm{Cd}^{2+}, \mathrm{Cr}^{3+}, \mathrm{Mo}^{\mathrm{VI}}, \mathrm{Ce}^{\mathrm{IV}}$, $\mathrm{Sb}^{3+}, \mathrm{Cr}{ }^{\mathrm{VI}}, \mathrm{Se}^{\mathrm{IV}}, \mathrm{Fe}^{3+}, \mathrm{Ag}^{+}, \mathrm{Ba}^{2+}, \mathrm{As}^{3+}, \mathrm{Pb}^{2+}, \mathrm{In}^{3+}, \mathrm{Tl}^{+}, \mathrm{Mn}^{2+}$, $\mathrm{Pd}^{2+}, \mathrm{V}^{\mathrm{V}}, \mathrm{Be}^{2+}, \mathrm{Sn}^{2+}, \mathrm{Bi}^{2+}, \mathrm{Zn}^{2+}, \mathrm{Hg}^{+}$, and $\mathrm{Hg}^{2+}$. Cobalt, iron, and copper are interfering ions in spectrophotometeric determination of nickel using furildioxime [15]. Here, using nonionic micellar solutions, no interference was observed from iron and copper while cobalt interference remains problem and was selectively removed using modified XAD16.

Sample solution $(5 \mathrm{~mL})$ containing different metal ions including $\mathrm{Ni}$ and cobalt was passed through column packed with $0.2 \mathrm{~g}$ of modified XAD-16. Nitroso R salt complexes of both $\mathrm{Ni}$ and cobalt were retained on column. Therefore, in order to recover retained $\mathrm{Ni}$, column was washed with $2.5 \mathrm{~mL}$ of $1 \mathrm{~N} \mathrm{HNO}_{3}$ [12]. Cobalt-furildioxime complex is stable at lower $\mathrm{pH}\left(1 \mathrm{~N} \mathrm{HNO}_{3}\right)$ thus remain attached with modified resin while $\mathrm{Ni}$-furildioxime decomposes and gets eluted with acid. The $\mathrm{pH}$ of eluent was neutralized with $\mathrm{NaOH}$ and 50 or $500 \mu \mathrm{Ls}$ injected in the flowing stream of reagent as mentioned above.

\subsection{Applications}

3.2.1. Determination of Nickel in Synthetic Mixtures. Several synthetic mixtures of varying compositions containing nickel and diverse ions of known concentration were determined by the present method. The results are shown in Table 3.

3.2.2. Determination of Nickel in Cigarette Samples. The proposed method was applied to the determination of nickel tobacco samples. $5 \mathrm{~g}$ of each tobacco sample was placed in a breaker of $100 \mathrm{~mL}$ capacity and after adding $2 \mathrm{~mL}$ of concentrated $\mathrm{HNO}_{3}$, the sample was heated almost to dryness on a hot plate at $110^{\circ} \mathrm{C}$, then $2 \mathrm{~mL}$ of concentrated $\mathrm{HNO}_{3}$ was again added to the residue and the solution was heated at $150^{\circ} \mathrm{C}$ for $2 \mathrm{~h}$. After adding a further $2 \mathrm{~mL}$ of concentrated $\mathrm{HNO}_{3}$ and $1 \mathrm{~mL}$ of $60 \% \mathrm{HClO}_{4}$, the solution was heated at $150^{\circ} \mathrm{C}$ for $4 \mathrm{~h}$ until white fumes
TABLE 4: Determination of nickel in tobacco samples.

\begin{tabular}{lcc}
\hline Sample & Amount of nickel $\mu \mathrm{g} \mathrm{g}^{-1}$ & RSD $(\%), n=3$ \\
\hline Sample-1 & 0.760 & 1.3 \\
Sample-2 & 0.110 & 2.2 \\
Sample-3 & 0.75 & 1.4 \\
Sample-4 & 0.50 & 2.4 \\
Sample-5 & 0.00 & 0.00 \\
Sample-6 & 0.125 & 3.4 \\
Sample-7 & 0.60 & 1.4 \\
Sample-8 & 0.70 & 2.1 \\
Sample-9 & 0.150 & 2.9 \\
\hline
\end{tabular}

Table 5: Determination of nickel in Certified Reference Materials.

\begin{tabular}{|c|c|c|c|}
\hline CRM & Composition of CRM & Nickel found & $\%$ recovery \\
\hline Alloy & $\begin{array}{c}50 \% \text { nickel, } \\
50 \% \text { aluminium }\end{array}$ & 49.99 & 99.9 \\
\hline $\begin{array}{l}\text { BAS (69b) } \\
\text { stainless steel }\end{array}$ & $\begin{array}{c}18.6 \% \mathrm{Cr} \\
9.35 \% \text { nickel }\end{array}$ & 9.32 & 99.6 \\
\hline $\begin{array}{l}\text { BCS 261, } \\
\text { stainless steel }\end{array}$ & $\begin{array}{c}0.083 \% \mathrm{C}, 0.39 \% \mathrm{Si} \\
17.2 \% \mathrm{Cr}, 13.08 \% \mathrm{Ni} \\
0.71 \% \mathrm{Ta} \& \mathrm{Nb} \\
0.66 \% \mathrm{Mn}\end{array}$ & 19.0 & 105 \\
\hline
\end{tabular}

appeared. This procedure was repeated twice. Solution was cooled, filtered, and diluted with deionized water. The nickel content was assayed by standard addition method. Results are summarized in Table 4.

3.2.3. Validation of Method. Some of the reference materials were analysed by proposed method and \% recovery was calculated. The results are shown in Table 5.

\section{Conclusion}

A highly selective, sensitive, simple, and rapid method for the determination of nickel using furildioxime in nonionic micellar medium has been developed. Use of micelles eliminates the toxic organic solvents, otherwise, necessary. Using homogenous environment of organized assemblies, the system was coupled with FIA, which increases sample throughput and minimizes sample consumption. The method was successfully applied for the determination of nickel in tobacco samples and complex synthetic mixtures.

\section{Acknowledgment}

All the authors of the manuscript declare that they do not have a direct financial relation with any commercial identity mentioned in the paper that might lead to a conflict of interest for any of the authors.

\section{References}

[1] M. Miró, J. M. Estela, and V. C. Cerdà, "Application of flowing stream techniques to water analysis: part III. Metal ions: 
alkaline and alkaline-earth metals, elemental and harmful transition metals, and multielemental analysis," Talanta, vol. 63, no. 2, pp. 201-223, 2004.

[2] Q. Hu, G. Yang, Y. Zhao, and J. Yin, "Determination of copper, nickel, cobalt, silver, lead, cadmium, and mercury ions in water by solid-phase extraction and the RP-HPLC with UVVis detection," Analytical and Bioanalytical Chemistry, vol. 375, no. 6, pp. 831-835, 2003.

[3] M.-H. Zhang and Y.-Z. Liang, "Rapid and simultaneous determination of copper, cadmium, nickel, and cobalt in zinc electrolyte solutions by complex adsorption wave polarography," Journal of Trace and Microprobe Techniques, vol. 20, no. 1, pp. 1-14, 2002.

[4] Z. Benzo, E. Marcano, C. Gómez et al., "Simultaneous determination of nickel, iron, and copper in margarine by inductively coupled plasma-atomic emission spectroscopy after sample emulsification," Journal of AOAC International, vol. 85, no. 4, pp. 967-970, 2002.

[5] K. Sreenivasa Rao, T. Balaji, T. Prasada Rao, Y. Babu, and G. R. K. Naidu, "Determination of iron, cobalt, nickel, manganese, zinc, copper, cadmium and lead in human hair by inductively coupled plasma-atomic emission spectrometry," Spectrochimica Acta B, vol. 57, no. 8, pp. 1333-1338, 2002.

[6] D. Zendelovska, G. Pavlovska, K. Cundeva, and T. Stafilov, "Electrothermal atomic absorption spectrometric determination of cobalt, copper, lead and nickel traces in aragonite following flotation and extraction separation," Talanta, vol. 54, no. 1, pp. 139-146, 2001.

[7] N. I. Ershova and V. M. Ivanov, "Improvement of direct determination of trace nickel in environmental samples by diffuse reflection spectroscopy using chromaticity characteristics," Fresenius' Journal of Analytical Chemistry, vol. 367, no. 2, pp. 210-211, 2000.

[8] L. Füchtjohann, N. Jakubowski, D. Gladtke, G. Barnowski, D. Klockow, and J. A. C. Broekaert, "Determination of soluble and insoluble nickel compounds in airborne participate matter by graphite furnace atomic absorption spectrometry and inductively coupled plasma mass spectrometry," Fresenius' Journal of Analytical Chemistry, vol. 366, no. 2, pp. 142-145, 2000.

[9] N. Chimpalee, D. Chimpalee, P. Keawpasert, and D. Thorburn Burns, "Flow injection extraction spectrophotometric determination of nickel using bis(acetylacetone)ethylenediimine," Analytica Chimica Acta, vol. 408, no. 1-2, pp. 123-127, 2000.

[10] M. Tubino and C. A. R. Queiroz, "Flow injection visible diffuse reflectance quantitative analysis of nickel," Analytica Chimica Acta, vol. 600, no. 1-2, pp. 199-204, 2007.

[11] Q. Hu, G. Yang, Z. Huang, and J. Yin, "Determination of nickel with 2-(2-quinolylazo)-5-diethylaminoaniline as a chromogenic reagent," Analytical Sciences, vol. 19, no. 10, pp. 1449-1452, 2003.

[12] J. Fries and H. Getrost, Organic Reagents for Trace Analysis, vol. 99, E. Merck, Darmstadt, Germany, 1977.

[13] K. D. Anil, S. M. Khopkar, and R. A. Chalmer, Solvent Extraction of Metal, Van Nostrand Reinhold Company Ltd., London, UK, 1970.

[14] N. Memon and M. I. Bhanger, "Micellar liquid chromatographic determination of aluminum as its complex with 8-hydroxyquinoline-5-sulfonic acid," Acta Chromatographica, no. 14 , pp. 172-179, 2004.

[15] C. S. de Sousa and M. Korn, "Effects of ultrasonic irradiation on the spectrophotometric determination of nickel with dimethylglyoxime," Analytica Chimica Acta, vol. 444, no. 2, pp. 309-315, 2001.
[16] S. G. Ostlund and D. Y. Pharr, "Determination of cobalt(II) by flow injection analysis using a surfactant solvent system," Journal of Undergradute Chemistry Research, vol. 2, no. 1, 2004.

[17] N. Memon, M. J. Ahmed, and M. I. Bhanger, "Micellar flow injection spectrophotometric determination of indium and its application to the environmental samples," Pakistan Journal of Analytical Chemistry, vol. 6, no. 1, pp. 16-21, 2005.

[18] N. Memon, M. A. Memon, M. I. Bhanger, and M. H. Memon, "Flow injection spectrophotometric determination of ascorbic acid using iron(III)-bathophenathroline disulfonic sodium salt," The Nucleus, vol. 40, no. 1-4, pp. 115-118, 2003.

[19] A. Balouch, N. Memon, M. I. Bhanger, and M. Y. Khuhawar, "Utilization of picolinaldehyde-4-phenyl-3-thiosemicarbazone in sodium dodecylsulfate micelles for the spectrophotometric determination of iron, vanadium, and cobalt following partial least-squares regression analysis," Journal of AOAC International, vol. 92, no. 1, pp. 248-256, 2009.

[20] A. Gahler, A. Mitchell, and M. Mellon, "Colorimetric determination of nickel with alpha-furildioxime," Analytical Chemistry, vol. 23, no. 3, pp. 500-503, 1951.

[21] C. B. Ojeda, A. G. de Torres, F. S. Rojas, and J. M. C. Pavon, "Fluorimetric determination of trace amounts of gallium in biological tissues," Analyst, vol. 112, no. 11, pp. 1499-1501, 1987. 


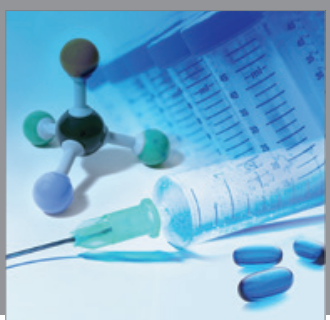

International Journal of

Medicinal Chemistry

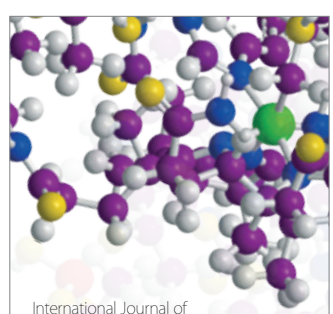

Carbohydrate Chemistry

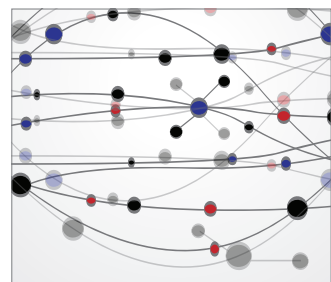

The Scientific World Journal
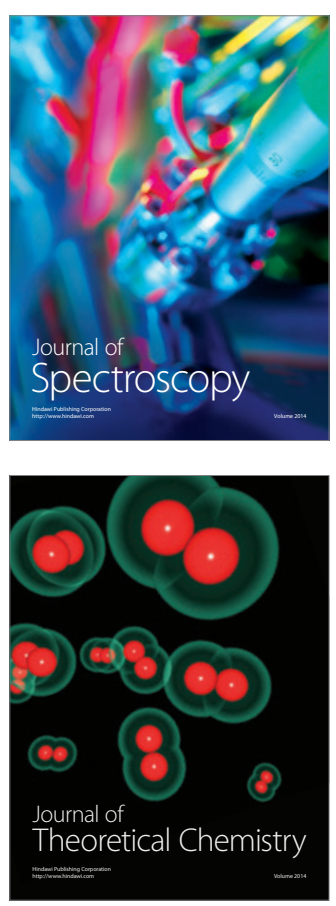
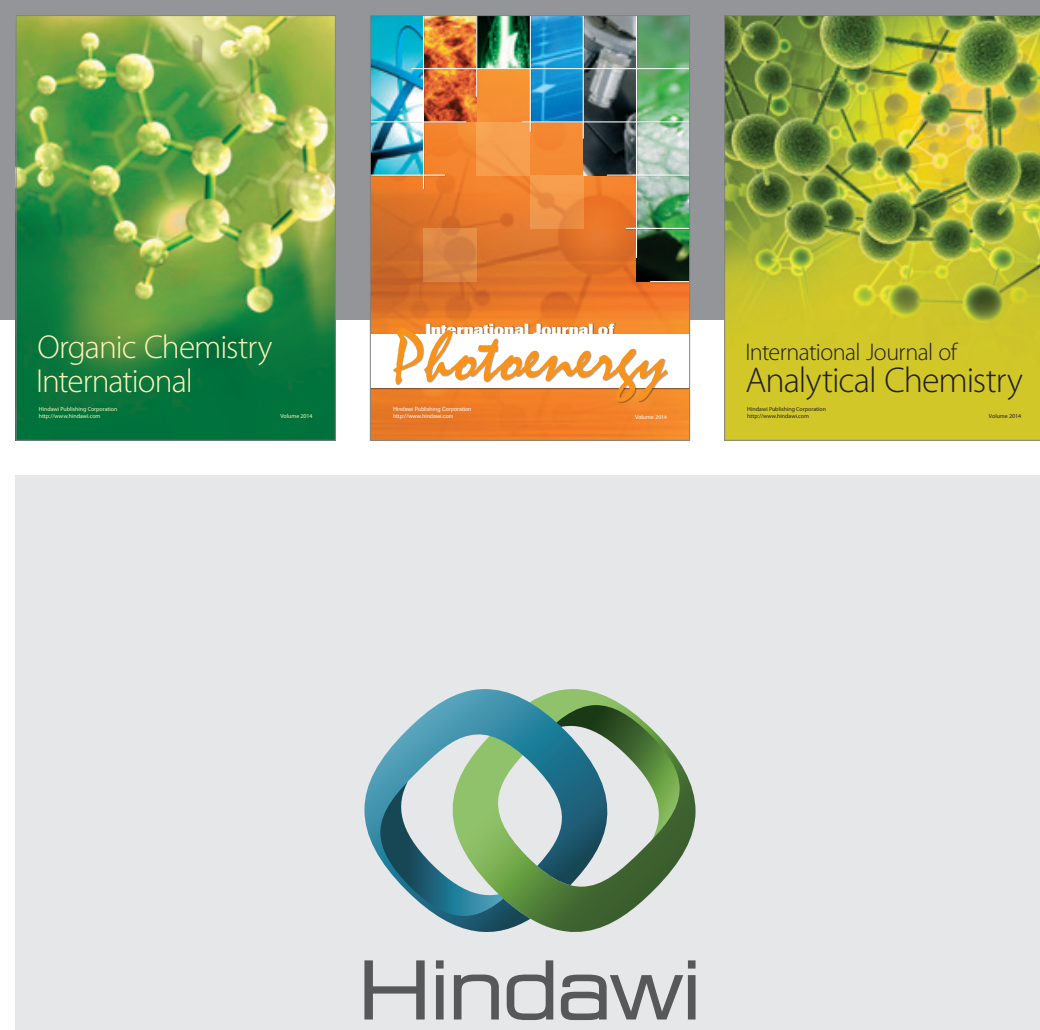

Submit your manuscripts at

http://www.hindawi.com
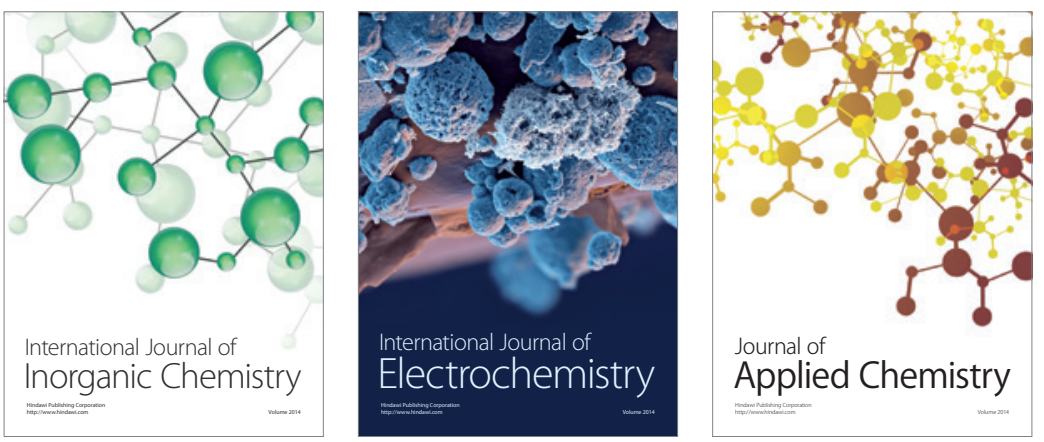

Journal of

Applied Chemistry
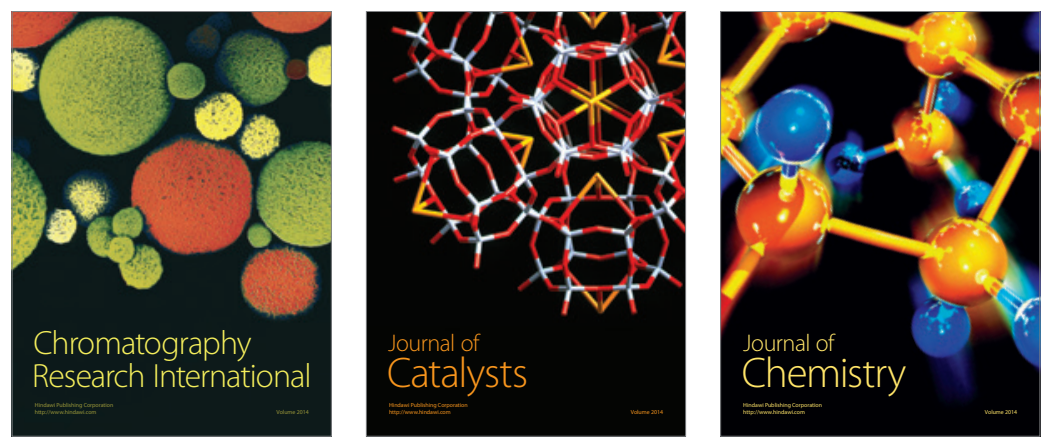
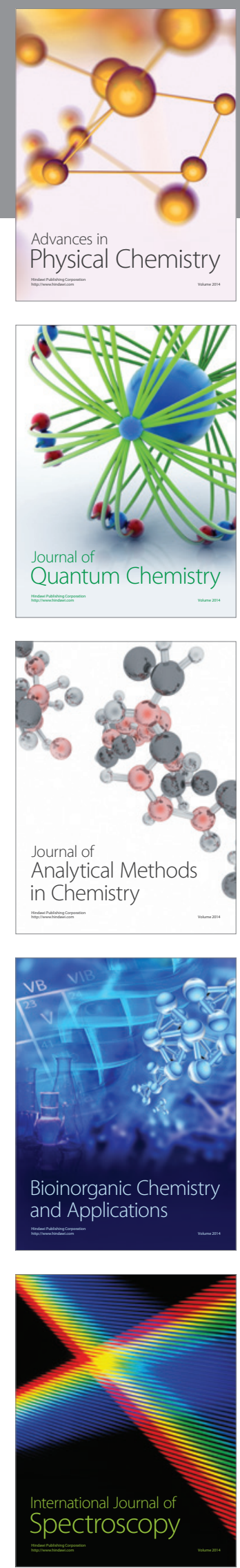